\title{
Rational Analysis of Thimi White Clay Deposits of Bhaktapur District, Nepal
}

\author{
Madhusudan Dhakal, Nirjan Duwal, Narendra M. Adhikari, Susan Joshi, and Jagadeesh Bhattarai
}

\begin{abstract}
Clay deposits become one of the natural mineral sources used abundantly as cost-effective raw materials for various industrial productions in recent years that use depend mainly on their quantification done by rational analysis. The rational analysis is a reliable and optimization method for the quantitative determination of all mineralogical components and structural formulae of the clay minerals that furnishes all their properties. However, no work reports the aspect of the quantitative analysis of the clay minerals deposited in Nepal. Considering the facts, the present work targeted to carry out the rational analysis of a bulk (BC), fine (FC), and $\mathrm{HCl}$-activated Thimi white clay $\left(\mathrm{FC}_{\mathrm{HCl}}\right)$ sample specimens to explore its potential uses in all industrial sectors, based on their chemical and mineralogical analysis data. Vermiculite, K-mica minerals with feldspars and quartz as assessors confirmed qualitatively in the Thimi white clay sample specimens, and their quantification of all the mineralogical components and their ionic structural formulae successfully estimated at present. The quantitative amounts of the iron-bearing vermiculite and $K$ mica minerals are increased with decreases of the quartz and Na-mica in the fine clay particles compared to the bulk clay sample. Acid-activated fine clay particles would apply as a suitable raw material for the quality production of white-wares on an industrial scale.
\end{abstract}

Index Terms - Clay deposits, Fractional analysis, Ionic formula, Vermiculite-mica mineral.

\section{INTRODUCTION}

Clay minerals are inorganic fine-grained and layerstructural hydrated alumino-silicates that originated mostly by chemical weathering or hydrothermal activities for thousands of years on the natural rocks found in the Earth [1]. The clay minerals are the components of soil and sedimentary rocks. It considers that about $75-80 \%$ of the surface Earth is of sedimentary type rock [2], and about $40 \%$ of the inorganic minerals in the sedimentary rock are of the clays [3]. But the clay minerals constitute only about 16 volume $\%$ of the total Earth's surface volume [4]. The quantity of clay minerals is up to approximately 35 weight $\%$ of sedimentary rocks [5]. The mineralogists define clays as an inorganic material having less than $2 \mu \mathrm{m}$ in equivalent spherical diameter particle size [6]. However, the soil scientists and engineers define it as the rock originated fine materials having a particle size less than $4 \mu \mathrm{m}$ without any significance about its mineralogical phases.

Submitted on October 24, 2020.

Published on February 28, 2021.

M. Dhakal, Department of Chemistry, T.C. campus, Tribhuvan University, Kathmandu, Nepal (at present: University of Science and Technology of China, China).

(e-mail: c.msdhaka@gmail.com)

N. Duwal, St. Xavier's College, Tribhuvan University, Kathmandu, Nepal. (e-mail: nirjanduwal@gmail.com)
The clay minerals are classified into four groups based on its structural units of tetrahedral silicate $(\mathrm{T})$ and octahedral aluminate $(\mathrm{O})$ sheets as; kaolin, montmorillonite/smectite, mica, and chlorite, and among the thirty types of pure clays are reported [7]. These clay minerals have two-layer structures, i.e., 1:1 and 2:1 layer structures. The 1:1 layer structure consists of the repetition of one $\mathrm{T}$ - and one $\mathrm{O}$-sheet, while in the 2:1 layer structure, one O-sheet sandwiched between two T-sheets [8]. In all-natural clay minerals, T- and O-sheets stacked one above the other, exposing surfaces of oxygen and hydroxyl that can interact with each other by hydrogen bonding between the layers [9]. Details about these four groups of the inorganic clay minerals, their properties and applications are described elsewhere [10]-[14].

The clay minerals are affordable, abundant, naturally occurring minerals found in many parts of the world [15]. They are continuously used since pre-historic times [16], depending on their mineralogical, chemical, and the structural properties so on [17], [18], it becomes one of the fascinating topics for the mineralogists, industrialists, and the business entrepreneurs. In modern days, the clay minerals act as costeffective natural scavengers for the environmental pollutant remedies [19]-[25], and as medicinal values for healing skin infection that is evident since the earliest recorded history and for the treatment of bacterial diseases also [26].

However, such uses of different types of clay minerals in various industrial sectors and purposes depend mainly on their properties. All clay properties affected mostly by their mineralogical phases, structural and compositional characteristics that frequently differ/deviate from its ideal structural and compositional, because of isomorphous substitution (e.g., $\mathrm{Al}^{3+}$ for $\mathrm{Si}^{4+}$ in the tetrahedral sheet and $\mathrm{Mg}^{2+} / \mathrm{Fe}^{2+}$ for $\mathrm{Al}^{3+}$ in the octahedral sheet) in the layeredalumino-silicates structure of the clays and such substitution enhanced almost all kinds of their properties. Hence, it is necessary to carry out rational analysis of the naturally deposited all classes of clay minerals for identifying their conclusive possibilities in industrial sectors and also for diverse uses [27]. The rational analysis allows anyone for the prediction of the physico-chemical and all possible technological properties of the clay minerals.

A real quantification of all mineralogical components present in a clay sample and its ionic structure based on its chemical composition and qualitative mineralogical phase analysis data is called rational (fractional) analysis [28], [29].

N. M. Adhikari, Pacific Northwest National Laboratory, Richland, US. (e-mail: narendramani07@yahoo.com)

S. Joshi, Central department of Chemistry, Tribhuvan University, Nepal. (e-mail: susanjoshi68@gmail.com)

J. Bhattarai, Central Department of Chemistry, Tribhuvan University, Nepal. (e-mail: bhattarai_05@yahoo.com) 
The purpose of the rational analysis of the clay samples is to determine their rational composition, percentage of all mineral components present in all classes of clay minerals, and finally become beneficial for the ionic formula determination. It gives us an abstract idea of the actual quantification of the clay materials. In the early time, the quantification method mostly based on the XRPD technique for the rational analysis and the ionic formula of the clay minerals believed to be highly accurate [30].

Nevertheless, the XRPD analysis results depend on human factors, sample preparation, data processing, and the selection of standards errors so on. Such quantification of clay minerals based on the XRPD analysis remains complex, most probably due to their unique structures, defects types, vary in chemical composition, and preferred orientation effects so on [31]. Such challenges mainly arise from the clay mineral characteristics such as an isomorphous substitution occurring in T- and O-sheet [32], [33], the interlayer cations of some clay minerals [34], variable structures [35], and preferred orientation [36] so on.

A critical appraisal about such challenging problems of the use of XRPD data for the quantification analysis of the clay minerals [4], and its merits as well as demerits are overviewed elsewhere [5]. In this context, the rational analysis becomes more informative and easy in connection with mixtures of high-grade clays, in which the variation of the ingredients can only be within comparatively narrow limits. It is proposed by which the composition of clay rocks be quantified, and the clay-forming minerals present can characterize because the rational analysis allowed the identification of rock-forming clay mineral and also determined the chemical formula [37][40].

Clay mineral deposited in Nepal studies by a few researchers in the past. The geo-mineralogical [41]-[47] and ceramic [48]-[54] properties of clay minerals/soils reported in previous studies. Similarly, inclusive studies of the porcelain properties of the raw kaolin clay deposits of Pachamane (Shivapuri Conservation area) and Daman (Makawanpur district) areas carry out since the 1990s [10], [55]-[59]. The clay minerals deposited in these two deposit areas are mainly $1: 1$ type of kaolin mineral that is most suitable for the production of white-wares of porcelain.

A qualitative mineralogical analysis of clay minerals showed that the Panchamane kaolin consisted mainly of 1:1 type tubular halloysite with subsidiary amounts of K-mica, feldspars, and minor amounts of gibbsite, and showed a very low $\mathrm{Fe}_{2} \mathrm{O}_{3}$ and $\mathrm{TiO}_{2}$ content [10]. Therefore, the whiteness of the sintered body at vitrification temperature range reported on a high level as similar to that of the raw materials used for the porcelain productions by Okura China Co. of Japan [56], [57]. Hence, it reported that the clay minerals deposited in Panchamane and Daman areas to be the best quality for making the best quality porcelain products in Nepal [58], [59]. Similarly, it reported that pegmatite occurring in the Panchamane area (named as Nardanda pegmatite) consists mainly of K-feldspar and muscovite, and the K-feldspar altered to kaolin along the cleavage, while the muscovite altered to kaolin around the rim of the pegmatite due to the weathering [43].

Quite apart from the above works, there are no detailed studies on the analysis of the mineralogical components quantitatively and their ionic structural formula of these clay deposits using rational analysis techniques. However, few studies on the qualitative analysis of the mineralogical phase [60], adsorption characteristics [23], and the corrosive nature [61], [62] of the Thimi clay/soil deposits reported previously. Under the circumstances, the present work aimed to carry out the rational analysis and ionic formulae determination of the bulk, fine, and $\mathrm{HCl}$-activated samples based on their chemical compositions and qualitative mineralogical phase analyses data. This study would be useful for further explorations of the Thimi white clay deposits in ceramic and other relevant industrial sectors of Nepal.

\section{MATERIALS AND METHODS}

\section{A. Description of the White Clay Deposit Site}

The Kathmandu Valley is a cup-shaped shallow basin that is surrounded by the five hills of Shivapuri, Nagarjun, Chandragiri, Pulchowki, and Nagarkot. It has typical lacustrine sediments that have attracted many geoscientists [63], [64]. However, these studies have a lack of information about the quantification of the surface/subsurface clay minerals analysis and sufficient description of the formation of each clay deposit area. Only a few researchers have carried out the lithological and mineralogical evaluation of Kathmandu Valley clay soils [42], [47], [63]. However, lack of detailed studies carried out on the rational analysis of white clay deposits between Sanothimi-Bhaktapur road and Araniko Highway in the Thimi area of Bhaktapur district located within the Kathmandu Valley of Nepal.

The Thimi white clay sampling site locates between $27^{\circ}$ 40 ' $30^{\prime \prime}-27^{\circ} 40^{\prime} 50^{\prime \prime} \mathrm{N}$ latitude and $85^{\circ} 23^{\prime} 40^{\prime \prime}-85^{\circ} 24^{\prime} 20^{\prime \prime} \mathrm{E}$ longitude, as shown in Fig. 1. It is accessible either by Araniko Highway or Sanothimi-Bhaktapur road, as described elsewhere [61]. The white clay sample that is locally known as 'Kamero Mato' occurs as a deposit over a wide area of the sampling site [23]. The clay sample was collected from the sampling site that represents the whole area of the sampling site.

\section{B. Clay Sample Preparation}

The bulk (BC) and fine (FC) clay samples with $<63 \mu \mathrm{m}$ and $<2 \mu \mathrm{m}$ particle size, respectively, were prepared using the US standard sieve, mesh no. 230 and the elutriation process based on Stoke's law using "Calgon" as described elsewhere [1], [10]. Besides, inorganic acid activation of the $\mathrm{FC}$ accomplished using $1 \mathrm{M} \mathrm{HCl}$ solution named as $\mathrm{FC}_{(\mathrm{HCl})}$. The $\mathrm{BC}, \mathrm{FC}$, and $\mathrm{FC}_{(\mathrm{HCl})}$ samples constituted of 2:1 type of vermiculite and mica (mainly of K-mica type) minerals with subsidiary amounts of quartz and feldspars as clay admixtures from the results of XRPD and FTIR examinations, as characterized by previous works [60].

\section{Chemical and Mineralogical Analysis}

The chemical constituents of these clay sample specimens confirmed the presence of high amounts of $\mathrm{SiO}_{2}$ with comparatively low $\mathrm{Al}_{2} \mathrm{O}_{3}$ (Table I) that indicates the presence of a lower amount of the vermiculite and mica minerals comparatively with feldspars and quart admixtures. These mineralogical and chemical analysis data provide anyone for the further exploration of the rational analysis of clay 
deposits. Methods about the mineralogical phase identification and the chemical analysis techniques described elsewhere [41].



Fig. 1. Thimi clay sampling site of Bhaktapur district, Nepal.

TABLE I: CHEMICAL COMPOSITION OF THE THIMI WHITE CLAY AFTER DIFFERENT TREATMENTS [41]

\begin{tabular}{cccc}
\hline & \multicolumn{3}{c}{ Weight $(\%)$} \\
Oxides & $\mathrm{BC}$ & $\mathrm{FC}$ & $\mathrm{FC}_{(\mathrm{HCl})}$ \\
\hline $\mathrm{SiO}_{2}$ & 66.50 & 60.18 & 61.33 \\
$\mathrm{Al}_{2} \mathrm{O}_{3}$ & 14.42 & 15.95 & 14.99 \\
$\mathrm{Fe}_{2} \mathrm{O}_{3}$ & 3.86 & 1.86 & 1.58 \\
$\mathrm{MgO}$ & 2.01 & 8.43 & 8.30 \\
$\mathrm{~K}_{2} \mathrm{O}$ & 2.16 & 2.64 & 2.43 \\
$\mathrm{Na}_{2} \mathrm{O}$ & 0.90 & 0.45 & 0.46 \\
$\mathrm{CaO}$ & 0.56 & 0.24 & 0.19 \\
$\mathrm{LOI}$ & 7.83 & 9.96 & 10.04 \\
$\mathrm{Misc}$ & 1.76 & 0.29 & 0.68 \\
\hline
\end{tabular}

$* 10 \overline{000}{ }^{\circ} \mathrm{C} ; \mathrm{BC}=$ bulk clay; $\mathrm{FC}=$ fine clay $\& \mathrm{FC}_{(\mathrm{HCl})}=\mathrm{HCl}$ activated fine clay.

\section{Rational Analysis of Clay Sample}

The calculation in the rational analysis method requires some suppositions, the main one being that the mineralogical phases present in the clay samples should have qualitatively identify with the help of recorded XRPD patterns, FTIR spectra, and elemental analysis [1]. A more considerable assumption (probably the one least justified) ascertained to identify an ideal formula of all possible clay minerals and admixture components in the samples. Also, an ionic structural formula of the $\mathrm{BC}, \mathrm{FC}$, and $\mathrm{FC}_{(\mathrm{HCl})}$ samples was calculated. For the purposes, qualitative XRPD, major element analysis with FTIR spectroscopy applied. The details of the overall rational analysis methods of the clay soil samples followed, as described elsewhere [1], [29].

\section{RESUlTS AND DISCUSSION}

\section{A. Chemical and Mineralogical Analysis}

As shown in Table I [41], the decrease of $\mathrm{SiO}_{2}$ with the increasing of $\mathrm{Al}_{2} \mathrm{O}_{3}$ content in the $\mathrm{FC}$ sample as a comparison with the $\mathrm{BC}$ indicated that the FC sample contained more amounts of clay minerals that also supported from XRPD patterns, as shown in Fig. 2. Similarly, the amounts of $\mathrm{MgO}$ and $\mathrm{K}_{2} \mathrm{O}$ are high in the $\mathrm{FC}$ sample and also in the acidactivated sample. The results indicate that the Thimi white clays constituted mainly of $\mathrm{SiO}_{2}$ and $\mathrm{Al}_{2} \mathrm{O}_{3}$ with a considerable amount of $\mathrm{MgO}$ and $\mathrm{K}_{2} \mathrm{O}$. It is worthwhile to cite the certainty that a substantial amount of $\mathrm{Fe}_{2} \mathrm{O}_{3}$ and $\mathrm{K}_{2} \mathrm{O}$ in clay minerals ascribed to be an iron-bearing muscovite, corresponding to K-mica [3], also known as white mica [65], which is supported from the XRPD patterns, as shown in Fig. 2 (a) and 2 (b). Moreover, from an industrial point of view, the $\mathrm{Al}_{2} \mathrm{O}_{3} / \mathrm{Fe}_{2} \mathrm{O}_{3}$ ratios for the $\mathrm{FC}$ and $\mathrm{FC}_{(\mathrm{HCl})}$ clay samples are 8.58 and 9.49 , respectively, i.e., more than 5.5, indicates that the $\mathrm{FC}$ and $\mathrm{FC}(\mathrm{HCl})$ sample can use for the manufacturing of the white-colored refractory ceramics, while the iron-rich $\mathrm{BC}$ sample having $3.74 \mathrm{Al}_{2} \mathrm{O}_{3} / \mathrm{Fe}_{2} \mathrm{O}_{3}$ ratio (i.e., less than 5.5), be suitable only for gray table-wares or building materials (i.e., tiles and bricks) [66].

The XRPD diffraction peak at around $1.5 \mathrm{~nm}$ might be the presence of either vermiculite or chlorite type of clay minerals that confirmed the presence of vermiculite type mineral from the result of a complete disappearance of the $1.49 \mathrm{~nm}$ for the $600-800{ }^{\circ} \mathrm{C}$ heated sample. Similar effect of a complete collapse of $1.49 \mathrm{~nm}$ peak to $1.0 \mathrm{~nm}$ at hightemperature treatment was reported in the two-water layers hydrated vermiculite clays [67]. Therefore, it believed that the Thimi white clay sample constituted mainly of vermiculite, muscovite type of K-mica with feldspars and quartz as clay assessors from Fig. 2 (b) and 2 (c).

Iron-bearing vermiculite and $\mathrm{K}$-mica minerals are treated with inorganic $1 \mathrm{M} \mathrm{HCl}$ acid to replace slightly the trivalent iron, and divalent calcium ions with divalent magnesium ions from the interlayers of the minerals and thus no observable altering the layers spacing changes in XRPD patterns of the $\mathrm{FC}_{(\mathrm{HCl})}$ sample, as shown in Fig. 2 (c). A similar behavior reports in an acid-activated $\mathrm{Ca}^{2+}$-bentonite [68]. These results supported that the reported vermiculite clay minerals in the Thimi clay should be of secondary origin and result from alteration of iron-bearing phlogopite by weathering, hydrothermal action or percolating groundwater or a combination of all above three effects, as reported previously [69]-[71]. In general, pure and homoionic vermiculite shows a series of higher order XRPD basal peaks that should be rational with the first order basal spacing peak between 1.4 and $1.5 \mathrm{~nm}$ [72]. Such effect does not observe in the XRPD patterns of the bulk and fine particles clay samples of the Thimi white clay. Therefore, it might be an equal possibility of the formation of the mixed-layer vermiculite-mica by the removal process of potassium from the K-mica mineral [73]. 

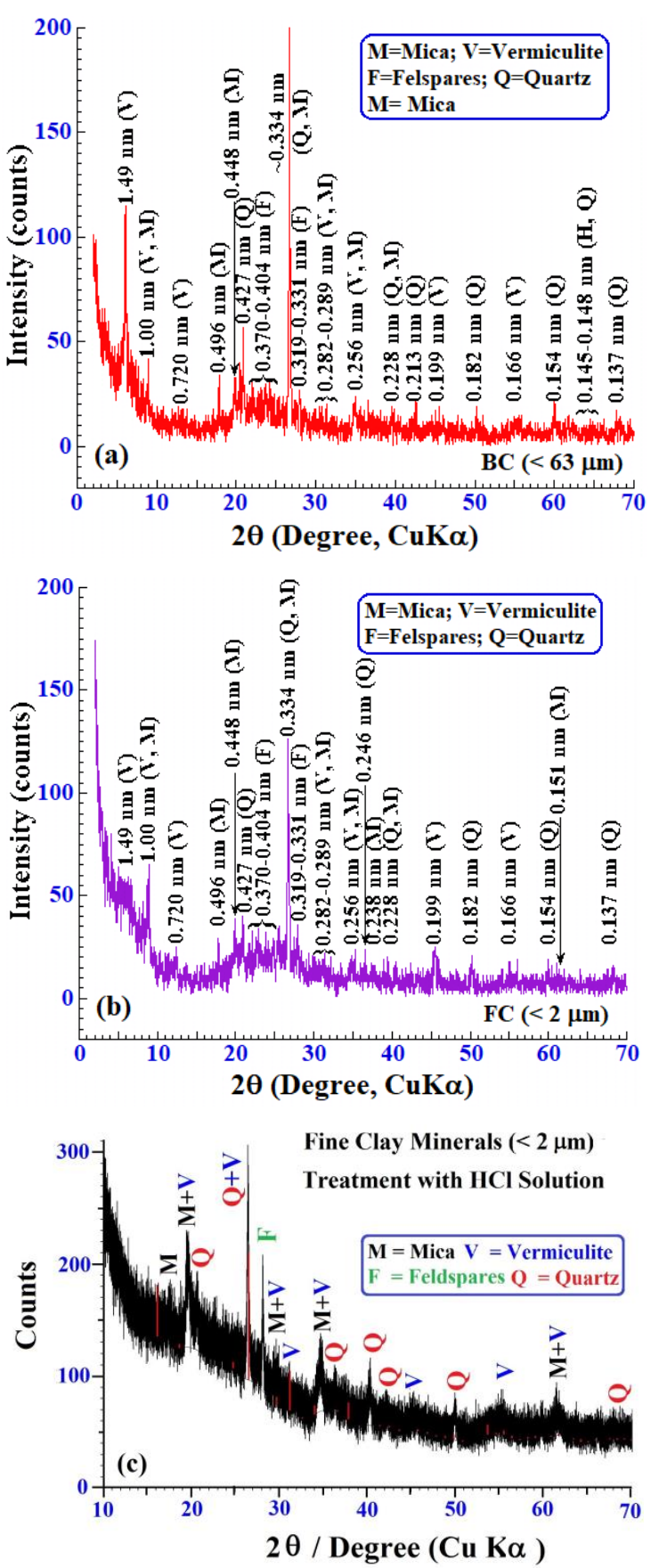

Fig. 2. XRD patterns of the (a) bulk clay, (b) fine clay, and (c) acidactivated fine particle clay sample of Thimi area of Bhaktapur, Nepal.

\section{B. Mineralogical Component Analysis}

For the rational analysis of the clay samples, it considered that all the three clay samples (i.e., $\mathrm{BC}, \mathrm{FC}$, and $\mathrm{FC}_{(\mathrm{HCl})}$ consist of vermiculite and $\mathrm{K}$-mica (muscovite) as main clay minerals with quartz and feldspar as the clay accessories, and their chemical compositions, as summarized above in Table I. It makes without difficulty for the rational analysis of the naturally deposited Thimi white clays if one commences with the mica minerals. Since 94.20 (i.e., mol. weight of $\mathrm{K}_{2} \mathrm{O}$ ) parts of weight of $\mathrm{K}_{2} \mathrm{O}$ correspond to 796.65 (i.e., mol. weight, as given in Table II) parts by weight of K-mica, so that one part of $\mathrm{K}_{2} \mathrm{O}$ is equivalent to (796.65/94.20) 8.457 part of K-mica, which is known as conversion factor, as summarized in Table III, for all clay mineral components including K-mica. Similarly, the conversion factors for all minerals present in the clay sample can be calculated.
TABLE II: MOLECULAR FORMULA OF DIFFERENT CLAY MiNERALS/OXIDES AND THEIR MOLECULAR WEIGHT

\begin{tabular}{ccc}
\hline $\begin{array}{c}\text { Mineral / } \\
\text { oxide }\end{array}$ & Molecular formula [1] & $\begin{array}{c}\text { Molecular } \\
\text { wt. }(\mathrm{g})[74]\end{array}$ \\
\hline Vermiculite & $\mathrm{Mg}_{3} \mathrm{AlSi}_{3} \mathrm{O}_{10}\left(\mathrm{OH} \rightarrow \mathrm{Mg}_{0.5} \cdot\left(\mathrm{H}_{2} \mathrm{O}\right)_{4.5}\right.$ & 471.34 \\
K-mica & $\mathrm{K}_{2} \mathrm{Al}_{6} \mathrm{Si}_{6} \mathrm{O}_{20}(\mathrm{OH})_{4}$ & 796.65 \\
Na-mica & $\mathrm{Na}_{2} \mathrm{Al}_{6} \mathrm{Si}_{6} \mathrm{O}_{20}(\mathrm{OH})_{4}$ & 764.43 \\
Quartz & $\mathrm{SiO}_{2}$ & 60.09 \\
Al-oxide & $\mathrm{Al}_{2} \mathrm{O}_{3}$ & 101.92 \\
K-oxide & $\mathrm{K}_{2} \mathrm{O}$ & 94.20 \\
Na-oxide & $\mathrm{Na}_{2} \mathrm{O}$ & 61.98 \\
\hline
\end{tabular}

TABLE III: CONVERSION FACTORS FOR RATIONAL ANALYSIS OF CLAY

\begin{tabular}{ccc}
\multicolumn{3}{c}{ MINERAL } \\
\hline Minerals & Found as & Conversion factor \\
\hline K-mica & $\mathrm{K}_{2} \mathrm{O}$ & 8.457 \\
Na-mica & $\mathrm{Na}_{2} \mathrm{O}$ & 12.333 \\
Alumina & Potash Mica & 0.384 \\
Alumina & $\mathrm{Soda} \mathrm{Mica}_{2}$ & 0.400 \\
Vermiculite & $\mathrm{Al}_{2} \mathrm{O}_{3}$ & 6.549 \\
Silica & Potash Mica & 0.453 \\
Silica & Soda Mica & 0.472 \\
Silica & Vermiculite & 0.383 \\
\hline
\end{tabular}

\section{Mica Minerals Analysis in BC Sample}

From the chemical composition analysis of the BC clay sample (Table I), the percentage of $\mathrm{K}_{2} \mathrm{O}$ in bulk Kamerotar clay sample estimated 2.16 and hence, the estimated K-mica is:

$$
2.16 \times 8.457=18.27 \%
$$

Similarly, the percentage of Na-mica in the BC sample is:

$$
0.90 \times 12.333=11.10 \%
$$

\section{Vermiculite Mineral Analysis in BC Sample}

For the analysis of the vermiculite mineral in the analyzed BC sample, first of all, it is reasonable to take into consideration that total alumina (14.42 weight \%, i.e., from Table I) in the BC sample should possibly combined with three mineral components, i.e., vermiculite, $\mathrm{K}$-mica and $\mathrm{Na}$ mica as characterized above from the XRPD patterns. Knowing one of the mineralogical component percent of Kmica and Na-mica as estimated above, it can further calculate the amount of alumina in both types of mica minerals. Subtracting this from the total alumina from chemical composition data (Table I) gives the alumina present in vermiculite mineral, from which the percentage of the vermiculite mineral in the bulk of the Thimi white clay sample can calculated as described below:

i. Alumina in K-mica:

Calculated percentage of alumina in potash-mica is $\{(3 \times 101.92 \times 100) / 796.65\} \quad 38.38 \%$ \% $\quad$ Therefore, the percentage alumina as potash-mica is:

$$
18.27 \times 0.3838=7.01 \%
$$

\section{ii. Alumina in Na-mica:}

The calculated percentage of alumina in soda-mica is $(3 \times 101.92 \times 100) /(764.43) 40.40 \%$. Therefore, the percentage alumina as soda-mica is:

$$
11.10 \times 0.4000=4.44 \%
$$




\section{iii. Alumina in Vermiculite:}

We know that the percentage of alumina in the Kamerotar bulk clay sample was reported as $14.42 \%$ as tabulated in Table I. Hence the percentage alumina combined as vermiculite is equal to (14.42-7.01-4.44) $2.97 \%$. Consequently, the total percentage of vermiculite in the BC of the Thimi white sample is estimated to be:

$$
(2.97 \times 471.34) /(101.92)=13.74 \%
$$

\section{Silica Content Analysis in BC Sample:}

The total silica $\left(\mathrm{SiO}_{2}\right)$ mentioned in Table I consists not only of quartz silica but also combined with micas and vermiculite. Therefore, the amount of combined silica first calculated in the same way as for alumina, and the combined silica is then subtracted from the total silica, giving the free quartz. The determination methods of silica in potash-mica, soda-mica, and vermiculite minerals and the free quart discuss below.

\section{i. $\quad$ Silica in K-mica:}

Calculated percentage of silica in potash-mica is $\{(6 \times 60.09 \times 100) / 796.65\} 46.26 \%$. Therefore, the percentage silica as potash-mica is:

$$
18.27 \times 0.4526=8.27 \%
$$

\section{ii. Silica in Na-mica:}

Calculated percentage of silica in soda-mica is $\{(6 \times 60.09 \times 100) / 764.43\} 47.16 \%$. Therefore, the percentage silica as soda-mica is:

$$
11.10 \times 0.4716=5.23 \%
$$

\section{iii. Silica in vermiculite:}

The calculated percentage of silica in vermiculite is:

$$
(3.0 \times 60.09 \times 100) /(471.34)=38.25 \%
$$

Therefore, the percentage silica as vermiculite is:

$$
0.3825 \times 13.74=5.26 \%
$$

We know that the weight percentage of silica in the $\mathrm{BC}$ sample of the Thimi white clay reported as $66.50 \%$ (Table I). Hence, the total percentage of the silica (free quartz) is:

$$
66.50-8 \cdot 27-5 \cdot 23-5 \cdot 26=47.74 \%
$$

\section{Miscellaneous Content Analysis in BC Sample}

It is noteworthy for mentioning here that the total of major constituents from short of $100 \%$ by $9.15 \%$, and this latter assumed to miscellaneous oxides and organic matter that are not included in the calculation.

From the above discussion, it can successfully carry out the rational analysis of the different mineralogical components in the Thimi bulk clay (BC) sample, and similar method/formula applied for the rational analysis of the clay components in the fine $(\mathrm{FC})$ and $\mathrm{HCl}$ activated $\mathrm{FC}_{(\mathrm{HCl})}$ samples, and results summarized in Table IV.

\section{Calculation of Ionic Formula of Clay Minerals}

In general, the natural clay minerals frequently vary from its ideal formula because of an isomorphous substitution. The nature and degree of substitution enables the species to be identified in the case of vermiculite mineral also. Therefore, it is meaningful to have a standard method of calculating the ionic formula of a mineral from the chemical analysis, assuming the clay mineral specimen to be pure. As noted above, the XRPD analysis confirmed that the Thimi white clay constituted mainly of vermiculite and mica minerals with other accessories (Fig. 2), the chemical composition (Table I), and mineralogical components analysis (Table IV). Such properties of any class of the natural clay deposits play significant roles in ascribing their industrial and other

\begin{tabular}{|c|c|c|c|}
\hline \multirow[b]{2}{*}{ Minerals } & \multicolumn{3}{|c|}{ Weight $(\%)$ estimated in } \\
\hline & $\mathrm{BC}$ & FC & $\mathrm{FC}_{(\mathrm{HCl})}$ \\
\hline Potash-Mica & 18.27 & 22.33 & 20.56 \\
\hline Soda-Mica & 11.10 & 5.55 & 5.67 \\
\hline Vermiculite & 13.74 & 23.86 & 22.34 \\
\hline Quartz & 47.74 & 38.32 & 40.81 \\
\hline Miscellaneous & 9.15 & 9.94 & 10.62 \\
\hline
\end{tabular}
applications successfully. Besides, more important information about the ionic formula of the clay minerals would help describe their clay minerals properties, especially as the cost-effective natural adsorbent for the environmental pollutant remedies and as medicinal values so on.

For the calculation of the ionic formula of a natural clay mineral, it should be firstly considered an ideal formula of the mineral. The actual formula of the vermiculite mineral is as given in equation (11), from which all vermiculites may derive by substitution.

$$
\mathrm{Mg}_{3} \mathrm{AlSi}_{3} \mathrm{O}_{10}(\mathrm{OH})_{2} \rightarrow \mathrm{Mg}_{0.5} \cdot\left(\mathrm{H}_{2} \mathrm{O}\right)_{4.5}
$$

The total number of negative charges is 22 in this formula of the vermiculite clay mineral that is balanced by an equal number of positive or cationic charges. Formula of the vermiculite and the chemical composition (Table V) must be derived from the ideal formula by substitution of other cations for $\mathrm{Al}, \mathrm{Si}$ or $\mathrm{Mg}$, so that the oxygen and hydroxyl ions remain unaltered. Therefore, the number of anionic charges due to oxygen and hydroxyl is 22 , so that the number of cation charges must be 22 .

Now, the first step in the calculation of the ionic formula of the clay minerals is to calculate the number of positive charges for each element present in the Thimi white clay minerals, as shown in Table V. Considering first $\mathrm{SiO}_{2}$, dividing by the molecular weight (60.09) gives the number of moles of $\mathrm{SiO}_{2}$ per 100 grams of materials, and multiply by 4 gives the total number of charges per 100 grams (since, $\mathrm{Si}^{4+}$ carries four positive charges), and the result shown in column (4) of Table V.

The same method carries out to calculate the number of charges per 100 grams for $\mathrm{Al}_{2} \mathrm{O}_{3}, \mathrm{MgO}$, and so on for the remaining elements. It should remember here that the number of charges per unit formula for $\mathrm{Al}, \mathrm{Mg}$, and other remaining elements present in the clay minerals are different, as given in column (3) of Table V. For example, a charge per unit 
formula for $\mathrm{Al}$ and $\mathrm{Mg}$ is 6 and 2, respectively.

$$
\begin{aligned}
& \frac{66.50 \times 4}{60.09}=\mathbf{4 . 4 2 7} \text { for } \mathrm{SiO}_{2} ; \frac{14.42 \times 6}{101.92}=\mathbf{0 . 8 4 9} \text { for } \mathrm{Al}_{2} \mathrm{O}_{3} \\
& \frac{3.86 \times 6}{159.68}=\mathbf{0 . 1 4 5} \text { for } \mathrm{Fe}_{2} \mathrm{O}_{3} ; \frac{2.01 \times 2}{40.31}=\mathbf{0 . 1 0 0} \text { for } \mathrm{MgO} \\
& \frac{0.56 \times 2}{56.08}=\mathbf{0 . 0 2 0} \text { for } \mathrm{CaO} ; \frac{0.90 \times 2}{61.98}=\mathbf{0 . 0 2 9} \text { for } \mathrm{Na}_{2} \mathrm{O} \\
& \frac{2.16 \times 2}{94.20}=\mathbf{0 . 0 4 6} \text { for } \mathrm{K}_{2} \mathrm{O}
\end{aligned}
$$

The number of charges for each element given in column in (4) was added and found 5.616 (i.e., $4.427+0.849+0.145$ $+0.100+0.046+0.029+0.020=5.616)$. However, this is simply the total number of charges per 100 grams. Each number of column (4), now multiply by the factor of $(22.00 / 5.616=) 3.9174$ to arrive at the number per unit formula which shown in column (5). For example, it is calculated as $(3.9174 \times 4.427=) 17.34$ for $\mathrm{SiO}_{2}$. In the same way, the charge for unit formula is calculated and tabulated in column (5), and the sum of this column should be 22 . Finally, to convert numbers of charges per unit formula numbers of atoms, the number figures of column (5) are divided in each case by the appropriate valence of the elements, given in column (6) of Table V.

$$
\begin{aligned}
& \frac{22 \times 4.427}{5.616}=\mathbf{1 7 . 3 4} \text { for } \mathrm{SiO}_{2} ; \frac{22 \times 0.849}{5.616}=\mathbf{3 . 3 3} \text { for } \mathrm{Al}_{2} \mathrm{O}_{3} \\
& \frac{22 \times 0.145}{5.616}=\mathbf{0 . 5 7} \text { for } \mathrm{Fe}_{2} \mathrm{O}_{3} ; \frac{22 \times 0.100}{5.616}=\mathbf{0 . 3 9} \text { for } \mathrm{MgO} \\
& \frac{22 \times 0.02}{5.616}=\mathbf{0 . 0 8} \text { for } \mathrm{CaO} ; \frac{22 \times 0.029}{5.616}=\mathbf{0 . 1 1} \text { for } \mathrm{Na}_{2} \mathrm{O} \\
& \frac{22 \times 0.046}{5.616}=\mathbf{0 . 1 8} \text { for } \mathrm{K}_{2} \mathrm{O}
\end{aligned}
$$

TABLE V: CALCULATION OF THE IONIC FORMULA FOR THE THIMI WHITE BULK CLAY (BC) SAMPLE

\begin{tabular}{cccccc}
\hline $\begin{array}{c}(1) \\
\text { Oxide }\end{array}$ & $\begin{array}{c}(2) \\
\text { Weight } \\
(\%)\end{array}$ & $\begin{array}{c}(3) \\
\text { No. of } \\
\text { charge per } \\
\text { unit formula }\end{array}$ & $\begin{array}{c}\text { No. of } \\
\text { charges per } \\
100 \mathrm{~g}\end{array}$ & $\begin{array}{c}\text { Charges per } \\
\text { unit formula }\end{array}$ & $\begin{array}{c}\text { No. of } \\
\text { atoms }\end{array}$ \\
\hline $\mathrm{SiO}_{2}$ & 66.50 & 4 & 4.427 & 17.34 & 4.34 \\
$\mathrm{Al}_{2} \mathrm{O}_{3}$ & 14.42 & 6 & 0.849 & 3.33 & 1.11 \\
$\mathrm{Fe}_{2} \mathrm{O}_{3}$ & 3.86 & 6 & 0.145 & 0.57 & 0.19 \\
$\mathrm{MgO}$ & 2.01 & 2 & 0.100 & 0.39 & 0.19 \\
$\mathrm{CaO}$ & 0.56 & 2 & 0.020 & 0.08 & 0.04 \\
$\mathrm{Na} 2$ & 0.90 & 2 & 0.029 & 0.11 & 0.11 \\
$\mathrm{~K}_{2} \mathrm{O}$ & 2.16 & 2 & 0.046 & 0.18 & 0.18 \\
$\mathrm{Total}^{2}$ & $90.41^{*}$ & - & 5.616 & 22.00 & - \\
$\left(\mathrm{Mg}_{0.14} \mathrm{Al}_{1.11} \mathrm{Si}_{4.34} \mathrm{O}_{10}(\mathrm{OH})_{2} \rightarrow\left(\mathrm{Mg}_{0.05} \mathrm{Fe}_{0.19}^{+3} \mathrm{Ca}_{0.04} \mathrm{Na}_{0.11} \mathrm{~K}_{0.18}\right) \cdot\left(\mathrm{H}_{2} \mathrm{O}\right)_{4.5}\right.$ \\
\hline
\end{tabular}

* The total weight falls short of $100 \%$ because the combined water and miscellaneous are not included, because they are not required for the calculation of the ionic formula.

To present these results as an ionic formula in the correct way, anions are first written down as $\mathrm{O}_{10}(\mathrm{OH})_{2}$, and the final ionic structural formula for the Thimi white bulk clay minerals written, as shown at the bottom of Table V. Similarly, the ionic structural formula for the fine clay mineral and the $\mathrm{HCl}$ treated-fine clay minerals collected from the sampling area of Nepal calculated, and the results are summarized in Tables VI and VII, respectively.

TABLE VI: CALCULATION OF THE IONIC FORMULA FOR THE CLAY FRACTION OF THIMI WHITE (FC) SOIL SAMPLE

\begin{tabular}{cccccc}
\hline $\begin{array}{c}(1) \\
\text { Oxide }\end{array}$ & $\begin{array}{c}(2) \\
\text { Weight } \\
(\%)\end{array}$ & $\begin{array}{c}(3) \\
\text { No. of charge } \\
\text { per unit } \\
\text { formula }\end{array}$ & $\begin{array}{c}(4) \\
\text { No. of } \\
\text { charge per } \\
100 \mathrm{~g}\end{array}$ & $\begin{array}{c}\text { Charges per } \\
\text { Unit Formula }\end{array}$ & $\begin{array}{c}(6) \\
\text { No. of } \\
\text { atoms }\end{array}$ \\
\hline $\mathrm{SiO}_{2}$ & 60.18 & 4 & 4.006 & 15.99 & 4.00 \\
$\mathrm{Al}_{2} \mathrm{O}_{3}$ & 15.95 & 6 & 0.939 & 3.75 & 1.25 \\
$\mathrm{Fe}_{2} \mathrm{O}_{3}$ & 1.86 & 6 & 0.070 & 0.28 & 0.09 \\
$\mathrm{MgO}$ & 8.43 & 2 & 0.418 & 1.67 & 0.84 \\
$\mathrm{~K}_{2} \mathrm{O}$ & 2.64 & 2 & 0.056 & 0.22 & 0.22 \\
$\mathrm{Na} 2 \mathrm{O}$ & 0.45 & 2 & 0.014 & 0.06 & 0.06 \\
$\mathrm{CaO}$ & 0.24 & 2 & 0.008 & 0.03 & 0.01 \\
$\mathrm{Total}^{2}$ & $89.75^{*}$ & - & 5.511 & 22.00 & - \\
$(\mathrm{Mg}$ & $\mathrm{Al}_{1.25} \mathrm{Si}_{4.00} \mathrm{O}_{10}(\mathrm{OH})_{2} \rightarrow\left(\mathrm{Mg}_{0.21} \mathrm{Fe}_{0.09}^{+3} \mathrm{Ca}_{0.01} \mathrm{Na}_{0.06} \mathrm{~K}_{0.22}\right) \cdot\left(\mathrm{H}_{2} \mathrm{O}\right)_{4.5}$
\end{tabular}

* The total weight falls short of $100 \%$ because the combined water and miscellaneous are not included, because they are not required for the calculation of the ionic formula.

TABLE VII: CALCULATION OF THE IONIC FORMULA FOR THE HCl-ACTIVATED Clay FRACTION SAMPLE

\begin{tabular}{cccccc}
\hline $\begin{array}{c}(1) \\
\text { Oxide }\end{array}$ & $\begin{array}{c}(2) \\
\text { Weight } \\
(\%)\end{array}$ & $\begin{array}{c}\text { No. of charge } \\
\text { per unit } \\
\text { formula }\end{array}$ & $\begin{array}{c}\text { No. of } \\
\text { charges per } \\
100 \mathrm{~g}\end{array}$ & $\begin{array}{c}(5) \\
\text { Charges per } \\
\text { unit formula }\end{array}$ & $\begin{array}{c}(6) \\
\text { No. of } \\
\text { atoms }\end{array}$ \\
\hline $\mathrm{SiO}_{2}$ & 61.33 & 4 & 4.083 & 16.30 & 4.08 \\
$\mathrm{Al}_{2} \mathrm{O}_{3}$ & 14.99 & 6 & 0.882 & 3.52 & 1.17 \\
$\mathrm{Fe}_{2} \mathrm{O}_{3}$ & 1.58 & 6 & 0.059 & 0.24 & 0.08 \\
$\mathrm{MgO}$ & 8.30 & 2 & 0.412 & 1.64 & 0.82 \\
$\mathrm{~K}_{2} \mathrm{O}$ & 2.43 & 2 & 0.052 & 0.21 & 0.21 \\
$\mathrm{Na}_{2} \mathrm{O}$ & 0.46 & 2 & 0.015 & 0.06 & 0.06 \\
$\mathrm{CaO}$ & 0.19 & 2 & 0.007 & 0.03 & 0.01 \\
$\mathrm{Total}^{2}$ & $89.18^{*}$ & - & 5.510 & 22.00 & - \\
$\left(\mathrm{Mg}_{0.58} \mathrm{Al}_{1.17} \mathrm{Si}_{4.08} \mathrm{O}_{10}(\mathrm{OH})_{2} \rightarrow\left(\mathrm{Mg}_{0.24} \mathrm{Fe}_{0.08}^{+3} \mathrm{Ca}_{0.01} \mathrm{Na}_{0.06} \mathrm{~K}_{0.21}\right) \cdot\left(\mathrm{H}_{2} \mathrm{O}\right)_{4.5}\right.$ \\
\hline
\end{tabular}

* The total weight falls short of $100 \%$ because the combined water and miscellaneous are not included, because they are not required for the calculation of the ionic formula.

\section{CONCLUSION}

Clay minerals are naturally occurring, inexpensive, and available in large quantities on the Earth surface that are most important for geological, agricultural, and environmental investigations. Many acceptable, authentic, and trustworthy methods are practiced for the qualitative identification of the clay minerals. However, a very few reliable, tranquil, and demanding methods for the quantitative analysis of the clay minerals and their structural information established so far as the qualitative analysis. In this regard, the present work suggested the uses of an optimization method of the rational analysis for the quantitative determination of the Thimi white clay based on the qualitative chemical and mineralogical information.

The fundamental principles and processes of the rational analysis method are successfully made clear for the quantitative determination of the clay mineral percentage and their ionic structures. The outcomes of the rational analysis method prove the simplicity and efficacy of the approach. Present work would be able to further explore the Thimi white clay deposits in ceramic and other relevant industrial sectors of Nepal. 


\section{ACKNOWLEDGMENT}

The University Grants Commission-Nepal, Bhaktapur is highly acknowledged for its research grants of the Masters' Thesis Supports to MD and NMR, the Faculty Research Grant-S\&S-14-2072/073 to JB and ND for carrying out this work in the Central Department of Chemistry, Tribhuvan University. Authors are thankful to Professor Dr. Lalu Prasad Paudel, Central Department of Geology, TU and Nepal Academy of Science and Technology (NAST), Lalitpur for providing the XRPD facilities.

\section{REFERENCES}

[1] W. E. Worrall, Clay and Ceramic Raw Materials, $2^{\text {nd }}$ ed., London/New York: Elsevier Applied Science Publishers, pp. 27-47 \& pp. 180-185, 1986.

[2] B. B. Velde, and A. Meunier, The Origin of Clay Minerals in Soils and Weathered Rocks, Heidelberg, Berlin: Springer-Verlag, pp. 406, 2008

[3] C. E. Weaver, and L. D. Pollard, The Chemistry of Clay Minerals, Amsterdam/New York: Elsevier Scientific Pub. Co., pp. 213, 1973.

[4] T. Al-Ani, and O. Sarapää, Clay and Clay Mineralogy: PhysicalChemical Properties and Industrial Uses, Report-M19/3232/2008/41, Finland: Geological Survey of Finland (GTK), p. 4, 2008.

[5] Z. Zhou, D. Liu, H. Bu, L. Deng, H. Liu, P. Yuan, P. Du, and H. Song, "XRD-based quantitative analysis of clay minerals using reference intensity ratios, mineral intensity factors, Rietveld, and full pattern summation methods: A critical review", Solid Earth Sciences, vol. 3 , no. 1, pp. 16-29, 2018. https://doi.org/10.1016/j.sesci.2017.12.002.

[6] S. Guggenheim, and R. T. Martin, "Definition of clay and clay mineral, Joint report of the AIPEA nomenclature and CMS nomenclature committee", Clays and Clay Minerals, vol. 43, no. 2, pp. 255-256, 1995. https://doi.org/10.1346/CCMN.1995.0430213.

[7] I. Savic, S. Stojiljkovic, I. Savic, and D. Gajic, "Industrial application of clay and clay minerals", in Clays and Clay Minerals: Geological origin, Mechanical Properties and Industrial Applications, L.R. Wesley, Ed., New York, USA: Nova Science Publishers, Inc., 2014 ch. 15 , pp. $379-402$.

[8] M. F. Brigatti, E. Galan, and B. K. G. Theng, "Structures and mineralogy of clay minerals", in Developments in Clay Science, vol. 1 , ch. 2, 2006, pp. 19-86. https://doi.org/10.1016/S1572-4352(05)010020 .

[9] R. E. Grim, Clay Mineralogy, $1^{\text {st }}$ ed., New York: McGraw-Hill, 1953, pp. 348-360.

[10] J. Bhattarai, and K. Okada, "Characterization of clay raw materials in Nepal and applicability for porcelain raw materials", Clay Science, vol. 8, pp. 392-402, 1992

[11] M. Massaro, C. G. Colletti, G. Lazzara, and S. Riela, "The use of some clay minerals as natural resources for drug carrier applications", Journal of Functional Biomaterials, vol. 9, no. 4, p. 58, 2018. https://doi.org/10.3390/jfb9040058.

[12] J. D. D. Moraes, S. R. A. Bertolino, S. L. Cuffini, D. F. Ducart, P. E Bretzke, and G. R. Leonardi, "Clay minerals: properties and applications to dermo-cosmetic products and perspectives of natural raw materials for therapeutic purposes- a review", International Journal of Pharmaceutics, vol. 534, no. 1-2, pp. 213-219, 2017. https://doi.org/10.1016/j.ijpharm.2017.10.031

[13] S. Mukherjee, "Clays: Industrial applications and their determinants", in The Science of Clays, Springer, Dordrecht, 2013, ch. 7, pp. 113-122. https://doi.org/10.1007/978-94-007-6683-9 7.

[14] B. O. Otunola and O. O. Ololade, "A review on the application of clay minerals as heavy metal adsorbents for remediation purposes", Environmental Technology and Innovation, vol. 18, 100692, 2020. https://doi.org/10.1016/j.eti.2020.100692.

[15] W. D. Kingery, "Ancient technology to modern science in ceramics and civilization", American Ceramic Society, vol. 1, pp. 1-25, 1985.

[16] H. H. Murray, "Traditional and new applications for kaolin, smectite, and palygorskite: a general overview", Applied Clay Science, vol. 17, no. 5-6, pp. 207-221, 2000. https://doi.org/10.1016/S01691317(00)00016-8.

[17] H. H. Murray, "Overview- clay mineral applications", Applied Clay Science, vol. 5, no. 5-6, pp. 379-395, 1991. https://doi.org/10.1016/0169-1317(91)90014-Z.

[18] A. Alshameri, X. Wei, H. Wang, Y. Fuguo, X. Chen, H. He, C. Yan, and $\mathrm{F} . \mathrm{Xu}$, "A review of the role of natural clay minerals as effective adsorbents and an alternative source of minerals", in Minerals, K.S.
Essa, Ed. IntechOpen, 2019, Ch. 3, pp. 59-63. https://doi.org/10.5772/intechopen.87260.

[19] A. Awasthi, P. Jadhao, and K. Kumari, "Clay nano-adsorbent: structures, applications and mechanism for water treatment", $S N$ Applied Sciences, vol. 1,1076 (pp. 21), 2019 https://doi.org/10.1007/s42452-019-0858-9.

[20] A. Stavitskaya, S. Batasheva, V. Vinokurov, G. Fakhrullina, V. Sangarov, Y. Lvov, and R. Fakhrullin, "Antimicrobial applications of clay nanotube-based composites", Nanomaterials (Basel), vol. 9, no. 5 , 708 (pp. 20), 2019. https://doi.org/10.3390/nano9050708

[21] S. Gu, X. Kang, L. Wang, E. Lichtfouse, and C. Wang, "Clay mineral adsorbents for heavy metal removal from wastewater: a review", Environmental Chemistry Letters, vol. 17, no. 2, pp. 629-654, 2018. https://doi.org/10.1007/s10311-018-0813-9.

[22] M. K. Uddin, "A review on the adsorption of heavy metals by clay minerals, with special focus on the past decade", Chemical Engineering Journal, vol. 36, pp. 438-462, 2017. https://doi.org/10.1016/j.cej.2016.09.029.

[23] N. Duwal, S. Joshi, and J. Bhattarai, "Study on the removable of methylene blue by calcined-Kamerotar clays as an eco-friendly lowcost adsorbent", International Journal of Advanced Research in Chemical Science, vol. 3, no. 11, pp. 1-8, 2016. https://doi.org/10.20431/2349-0403.0311001.

[24] S. Ismadji, F. E. Soetaredjo, and A. Ayucitra, "Natural clay minerals as environmental cleaning agents", in Clay Materials for Environmental Remediation, Berlin, Germany: Springer, 2015, pp. 5-17. https://doi.org/10.1007/978-3-319-16712-1_2.

[25] J. Bhattarai, "Adsorption of indigo-carmine dye on kaolin in aqueous medium”, Tribhuvan University Journal, vol. 17, no. 1, pp. 10-19, 1994.

[26] S. E. Haydel, S. C. M. Remenih, and L. B. Williams, "Broad-spectrum in vitro antibacterial activities of clay minerals against antibioticsusceptible and antibiotic-resistant bacterial pathogens", The Journal of Antimicrobial Chemotherapy, vol. 61, no. 2, pp. 353-361, 2008. https://doi.org/10.1093/jac/dkm468.

[27] T. Vakalova, V. Pogrebenkov, V. Vereshagin, T. Khabas, and I. Revva, "Optimizing rational chemical analysis for quantitative determination of the composition of clay in soils", Applied Clay Science, vol. 163, pp. 153-163, 2018. https://doi.org/10.1016/j.clay.2018.07.014.

[28] C. Coelho, N. Roqueiro, and D. Hotza, "Rational mineralogical analysis of ceramics", Materials Letters, vol. 52, no. 6, pp. 394-398, 2002. https://doi.org/10.1016/S0167-577X(01)00429-3.

[29] B. Fabri, C. Fiori, A. Krajewski, R. Valmori, and A. Tenaglia, "Comparison between traditional mineralogical and computerized rational analysis of ceramic raw materials", Journal de Physique (Paris), Colloque, vol. 47, pp. 57-62, 1986 https://doi.org/10.1051/jphyscol:1986109.

[30] J. Srodon, "Identification and quantitative analysis of clay minerals", in Developments in Clay Science, vol. 1, 2006, Ch. 12.2, pp. 765-787. https://doi.org/10.1016/S1572-4352(05)01028-7.

[31] J. Srodon, "Quantitative mineralogy of sedimentary rocks with emphasis on clays and with applications to K-Ar dating", Mineralogical Magazine, vol. 66, no. 5, pp. 677-687, 2002. https://doi.org/10.1180/0026461026650055.

[32] J. Srodon, and D. K. McCarty, "Surface area and layer charge of smectite from CEC and EGME/H2O retention measurements", Clays and Clay Minerals, vol. 56, no. 2, pp. 155-174, 2008. https://doi.org/10.1346/CCMN.2008.0560203.

[33] D. Liu, P. Yuan, H. Liu, J. Cai, D. Tan, H. He, J. Zhu, and T. Chen "Quantitative characterization of the solid acidity of montmorillonite using combined FTIR and TPD based on the $\mathrm{NH}_{3}$ adsorption system", Applied Clay Science, vol. 80-81, pp. 407-412, 2013. https://doi.org/10.1016/j.clay.2013.07.006

[34] J. -C., Viennet, F. Hubert, E. Ferrage, E. Tertre, A. Legout, and M. -P. Turpault, "Investigation of clay mineralogy in a temperate acidic soil of a forest using X-ray diffraction profile modeling: beyond the HIS and HIV description”, Geoderma, vol. 241-242, pp. 75-86, 2015. https://doi.org/10.1016/j.geoderma.2014.11.004.

[35] J. Srodon, "Identification and quantitative analysis of clay minerals", in Developments in Clay Science, vol. 5, 2013, Ch. 2.2, pp. 25-49. https://doi.org/10.1016/B978-0-08-098259-5.00004-4.

[36] D. M. Moore, and R. C. Reynolds Jr., X-ray Diffraction and the Identification and Analysis of Clay Minerals, $2^{\text {nd }}$ ed., New York, USA Oxford University Press, 1997, p. 400.

[37] H. S. Washington, "The calculation of the rational analysis of clays", Journal of the American Ceramic Society, vol. 1, no. 6, pp. 405-421, 1918. https://doi.org/10.1111/j.1151-2916.1918.tb18605.x.

[38] H. S. Washington, "Rational analysis of clay-II", Journal of the American Ceramic Society, vol. 9, no. 1, pp. 61-86, 1926. https://doi.org/10.1111/j.1151-2916.1926.tb18301.x. 
[39] K. P. Kaphle, "Mineral Resources of Nepal and Their Present Status", Kathmandu, Nepal: Published by Nepal Geological Society, May 15, 2020 , pp. $1-15$

[40] B. Neupane, and D. P. Adhikari, "Role of clay minerals in the occurrence of landslides along Narayangarh-Mugling Highway section, central Nepal", Journal of Nepal Geological Society, vol. 43 (Sp. Issue), pp. 301-308, 2011. Retrieved from https://www.researchgate.net/publication/282073426.

[41] M. Dhakal, N. Duwal, N. M. Adhikari, S. Joshi, and J. Bhattarai, "Genesis exploration of white clays deposited in Thimi area of Kathmandu Valley”, Journal of Nepal Chemical Society, vol. 42, no. 1 , pp. 80-88, 2021.

[42] M. R. Paudel, "Lithological and mineralogical variations: Indicator of provenance and paleo-environmental change of the Kathmandu Basin fill sediments, Nepal", in: Sixth Nepal Geological Congress on Geology, Natural Resources, Infrastructures, Climate Change and Natural Disasters, November 15-17, Kathmandu, Nepal, 2010.

[43] S. M. Rai, B. N. Upreti, S. Guillot, A. Pecher, and P. L. Fort, "Mineral chemistry (biotite, muscovite, garnet, and plagioclase) in the Kathmandu and Gosainkund regions, central Nepal Himalaya", Journal of Nepal Geological Society, vol. 30, pp. 55-66, 2004.

[44] J. Bhattarai, "Genesis of clay deposit in Panchamane area of Kathmandu, Nepal”, Journal of Nepal Geological Society, vol. 24 (Sp. Issue), pp. 20-21, 2001

[45] J. Stöcklin, "Geology of Nepal and its regional frame", Journal of Geological Society London, vol. 137, no. 1, pp. 1-34, 1980. https://doi.org/10.1144/gsjgs.137.1.0001

[46] J. Bhattarai, "Chemico-mineralogical investigation of chlorite minerals in Nepal and their firing properties", Tribhuvan University Journal, vol. 21 , no. 1, 1-12, 1998

[47] J. Stöcklin, and K. D. Bhattarai, "Geology of Kathmandu Area and Central Mahabharat Range, Nepal”, in Himalaya Report (unpubl.), Kathmandu, Nepal: Department of Mines and Geology, 1977,pp. 1-86.

[48] N. B. Bohara, D. B. Ghale, Y. P. Chapagain, N. Duwal, and J. Bhattarai, "Effect of firing temperature on physico-mechanical properties of contemporary clay brick productions in Lalitpur (Nepal)", Bangladesh Journal of Scientific and Industrial Research, vol. 55, no. 1, pp. 43-53, 2020. https://doi.org/10.3329/bjsir.v55i1.46731.

[49] P. Budhathoki, N. Duwal, and J. Bhattarai, "Investigation on physicosintering and mechanical properties of clay tiles available in Kathmandu Valley of Nepal", Asian Journal of Chemistry, vol. 30, no. 11, pp. 2515-2530, 2018. https://doi.org/10.14233/ajchem.2018.21509.

[50] N. B. Bohara, L. B. Bhat, D. B. Ghale, N. Duwal, and J. Bhattarai, "Investigation of the firing temperature effects on clay brick sample; part-I: mineralogical phase characterization", Bibechana, vol. 16, pp. 122-130, 2018. https://doi.org/10.3126/bibechana.v16i0.21319.

[51] Y. P. Chapagain, S. Sapkota, D. B. Ghale, N. B. Bohara, N. Duwal, and J. Bhattarai, "A case study on mineralogy and physico-mechanical properties of commercial bricks produced in Nepal", SN Applied Sciences, vol. 2, no. 11, 1856, 2020. https://doi.org/10.1007/s42452020-03535-y.

[52] D. B. Ghale, N. B. Bohara, N. Duwal, and J. Bhattarai, "Investigation on the mineralogical phase of ancient brick samples of Kathmandu valley (Nepal) using XRD and FTIR analysis", Rasayan Journal of Chemistry, vol. 12, no. 2, pp. 402-408, 2019 https://doi.org/10.31788/RJC.2019.1224034.

[53] J. Bhattarai, D. B. Ghale, Y. P. Chapagain, N. B. Bohara, and N. Duwal, "Study on the physical and mechanical properties of ancient clay brick samples of Kathmandu valley, Nepal", Tribhuvan University Journal, vol. 32, no. 2, pp. 1-18, 2018. https://doi.org/10.3126/tuj.v32i2.24699.

[54] P. Budhathoki, P. Paudal, R. R. Oli, N. Duwal, and J. Bhattarai, "Assessment on the characterization of mineralogical phase of ceramic tiles available in Kathmandu valley (Nepal) using XRD and FTIR analyses", International Journal of Applied Science and Biotechnology, vol. 6, no. 3, 238-243, 2018 https://doi.org/10.3126/ijasbt.v6i3.21171.

[55] J. Bhattarai, and B. R. Bhattarai, "X-ray photoelectron spectroscopy investigation on sintered-bodies of porcelain raw materials of Nepal", Analytical Sciences (supplement), vol. 17, a361-a363, 2001. https://doi.org/10.14891/analscisp.17asia.0.a361.0.

[56] J. Bhattarai, and K. Okada, "The effect of wet ball milling on physicomineralogical and sintering properties of porcelain raw materials", Nepal Journal of Science and Technology, vol. 2, pp. 5-16, 2000. https://www.nast.org.np/njst/index.php/njst/article/view/29.

[57] J. Bhattarai, and K. Okada, "Physico-chemical investigation of kaolin minerals of Panchmane area in Nepal", Journal of Nepal Chemical Society, vol. 17-18, pp. 12-21, 1999.

[58] J. Bhattarai, and K. Okada, "The effect of heating rate and soaking time on sintering behavior of some ceramic clay minerals", Journal of Nepal
Chemical Society, vol. 12, pp. 46-54, 1993. Retrieved from https://www.researchgate.net/publication/344387804.

[59] Bhattarai, J., Hayashi, S., Okada, K. (1992). "P7 Characterization of some clay raw materials in Nepal and their sintering behavior", In Proceedings of $36^{\text {th }}$ Annual Meeting of the Clay Science Society of Japan, Tokyo, Japan: The Clay Society of Japan, pp. 102-103. https://doi.org/10.11362/cssj2.36.0_102.

[60] N. Duwal, M. Dhakal, N. M. Adhikari, S. Joshi, and J. Bhattarai, Characterization of Kamerotar clays of Madhyapur Thimi Municipality of Bhaktapur, Nepal, Journal of University Grants Commission-Nepal, vol. 4, no. 1, pp. 54-66, 2015. Retrieved from https://www.researchgate.net/profile/Narendra_Mani_Adhikari/public ation/283245458.

[61] Y. R. Dhakal, K. P. Dahal, and J. Bhattarai, "Investigation on the soil corrosivity towards the buried water supply pipelines in Kamerotar town planning areas of Bhaktapur, Nepal”, Bibechana, vol. 10, pp. 82 91, 2014. https://doi.org/10.3126/bibechana.v10i0.8454.

[62] P. P. Bhandari, K. P. Dahal, and J. Bhattarai, "The corrosivity of soil collected from Araniko highway and Sanothimi areas of Bhaktapur Nepal", Journal of Institute of Science and Technology, vol. 18, no. 1 pp. 2013. 71-77, Retrieved from https://scholar.google.co.jp/citations?hl=en\&user=5oGd9oMAAAAJ.

[63] Y. R. Paudyal, R. Yatabe, N. P. Bhandary, and R. K. Dahal, "Basement topography of the Kathmandu Basin using microtremor observation", Journal of Asian Earth Sciences, vol. 62, pp. 627-637, 2013. https://doi.org/10.1016/j.jseaes.2012.11.011.

[64] R. Fujii, and H. Sakai, "Paleoclimatic changes during the last $2.5 \mathrm{myr}$ recorded in the Kathmandu Basin, Central Nepal Himalayas". Journal of Asian Earth Sciences, vol. 20, no. 3, pp. 255-266, 2002 https://doi.org/10.1016/S1367-9120(01)00048-7.

[65] H. Ries and H. B. Kummbel, "The Clays and Clay Industry of New Jersey", Treton, N.J., MacCrellish \& Quigley, Book and Job Printers, 1904 , pp. 619.

[66] M. Garcia-Valles, P. Alfonso, S. Martínez, and N. Roca, "Mineralogical and thermal characterization of kaolinitic clays from Terra Alta (Catalonia, Spain)”, Minerals, vol. 10, 142 (pp. 15), 2020. https://doi.org/10.3390/min10020142.

[67] C. Marcos, Y. C. Arango, and I. Rodriguez, "X-ray diffraction studies of the thermal behavior of commercial vermiculite", Applied Clay Science, vol. 42, no. 3-4, pp. 368-378, 2009 https://doi.org/10.1016/j.clay.2008.03.004.

[68] P. Komadel, and J. Madejová, "Acid activation of clay minerals", in Developments in Clay Science, vol. 1, 2006, Ch. 7.1, pp. 263-287. https://doi.org/10.1016/S1572-4352(05)01008-1.

[69] M. Rama, O. Eklund, S. Fröjdö, J.-H. Smatt, M. Lastusaari, and T. Laiho, "Characterization of altered mica from Sokli, Northern Finland”, Clays and Clay Minerals, vol. 67, no. 5, pp. 428-438, 2019. https://doi.org/10.1007/s42860-019-00041-0.

[70] R. Badreddine, F. Grandjean, D. Vandormael, A. -M. Fransolet, and G. J. Long, "A 57Fe Mössbauer spectral study of vermiculitization in the Palabora complex, Republic of South Africa", Clay Minerals, vol. 35 , no. 4, pp. 653-663, 2000. https://doi.org/10.1180/000985500547115.

[71] W. A. Bassett, "The geology of vermiculite occurrences", Clays and Clay Minerals, vol. 10, no. 1, pp. 61-69, 1961 https://doi.org/10.1346/CCMN.1961.0100106.

[72] G. W. Brindley, and G. Brown, "Crystal structures of clay minerals and their X-ray identification”, Monograph, no. 6, London: Mineralogical Society, 1984, pp. 349-356.

[73] R. T. Martin, S. W. Bailey, D. D. Eberl, D. S. Fanning, S. Guggenheim, H. Kodama, D. R. Pevear, J. Srodon, and F. J. Wicks, "Report of the clay minerals society nomenclature committee: Revised classification of clay materials", Clays and Clay Minerals, vol. 39, no. 3, pp. 333335, 1991. https://doi.org/10.1346/CCMN.1991.0390315.

[74] P. Atkins, and J. de Paula, “Atkins' Physical Chemistry", $10^{\text {th }}$ ed., New Delhi, India: Oxford Univ. Press, 2014

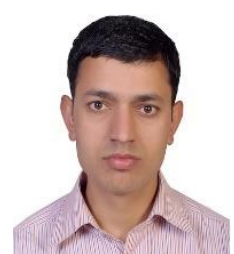

Madhusudan Dhakal had completed his MSc degree from Tribhuvan University, Nepal in 2015, and did his MSc dissertation on natural clay minerals of Nepal under the supervision of Prof. Jagadeesh Bhattarai, Central Department of Chemistry, Tribhuvan Univ. Now, he has been working as a PhD scholar at IMR, CAS affiliated to University of Science and Technology of China, Hefei, China under the Chinese government scholarship. He has published about half-dozen of articles in reputed journals.

Nirjan Duwal had completed his MSc degree in Chemistry from Central Department of Chemistry, Tribhuvan University, Nepal in 2013. Now, he has 
been working as a Lecturer of Chemistry at St. Xavier's College, affiliated to Tribhuvan University, Thapathali, Kathmandu, Nepal. Mr. Duwal has published more than one dozen of articles in reputed journals.

Narendra M. Adhikari had completed his $\mathrm{PhD}$ from Ohio University, Athens, US in 2019, and MSc in Chemistry from Central Department of Chemistry, Tribhuvan University. He did MSc dissertation on the characterization of clays and their adsorption properties under the supervision of Prof. J. Bhattarai, Central Department of Chemistry, Tribhuvan Univ. Now, he has been working as Postdoctoral Researcher at Pacific Northwest National Laboratory, Richland, US. He has published more than one and half dozens of articles in reputed journals.

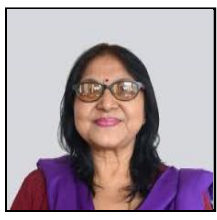

Susan Joshi had completed her $\mathrm{PhD}$ in natural products chemistry from Indian Institute of Technology, Delhi, India in 1999. She has been working more than thirty years as an Associate Professor of Chemistry in Central Department of Chemistry, Tribhuvan University, Kirtipur, Nepal. She has published more than three dozen of articles.

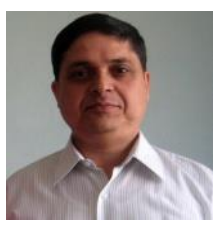

Jagadeesh Bhattarai had completed his $\mathrm{PhD}$ degree in the field of corrosion sciences from Institute of Materials Research (IMR), Tohoku University, Japan in 1998. He has been working more than thirty two years as a full Professor of Chemistry in Central Department of Chemistry, Tribhuvan University, Kirtipur, Nepal. He had carried out research works at Tokyo Institute of Technology (1991-92) as an UNESCO-Research Fellow, sponsored by Japanese Ministry of Education, Culture, Spots, Science and Technology (MEXT), Japan, and Tohoku Institute of Technology (2007-08), as Visiting Researcher. He has published more than ten dozen of articles in reputed national and international journals. Now, he is the Chief Editorial of Journal of Institute of Science \& Technology (JIST)- an official journal of Institute of Science and Technology, Tribhuvan University, Nepal. 